\title{
CAPTURE FISHERY IN NORTHERN TODOS OS SANTOS BAY, TROPICAL SOUTHWESTERN ATLANTIC, BRAZIL
}

\author{
Lucy Satiko Hashimoto Soares ${ }^{1 *}$, Juliana Pierrobon Lopez $^{l}$, Elizabeti Yuriko Muto ${ }^{l}$ and Roberto Giannini ${ }^{2}$
}

${ }^{1}$ Instituto Oceanográfico, Universidade de São Paulo

(Praça do Oceanográfico, 191, São Paulo, SP, Brasil, 05508-120)

${ }^{2}$ Alpina Briggs Defesa Ambiental S.A.

(Rua Tiguassu, 154, 09970-310 Diadema, SP, Brasil)

*Correspoding author: 1soares@usp.br

\begin{abstract}
A B S T R ACT
Information on marine and estuarine capture fishery activity in northern Todos os Santos Bay, northeastern Brazil, based on daily data collected between September 2003 and June 2005 is presented. Small-scale artisanal fishery in this area includes the use of traditional vessels both nonmotorized and motorized for locomotion, being carried out mainly by canoe or on foot, and involves many different kinds of gear, including gillnet, hook and line, seine nets, and traps. A total of 113 taxa were grouped into 77 resources, including 88 fish, 10 crustaceans, and 15 mollusks. Data on nominal catches of fish, crustaceans and mollusks are presented by month and location. A total of 345.2 tonnes of fishery resources were produced (285.4 tonnes of fish, 39.2 tonnes of fresh invertebrates, and 20.6 tonnes of processed invertebrates). Temporal variation in the fish catch was associated with the life cycle of the species or with the hydrographic conditions. The first-sale value of this catch amounted to around US\$ $615,000.00$, fishes representing $71.3 \%$ of it. A table of the average price of each fishery resource is presented. The results produced in this study may be considered a reference for future monitoring programs of fishery resources in the area.
\end{abstract}

\section{RESUMO}

Informações sobre a atividade pesqueira extrativa da região norte da Baía de Todos os Santos, Bahia, nordeste do Brasil são apresentadas, baseadas em coleta diária de dados, realizada entre setembro de 2003 e junho de 2005. Trata-se de uma atividade extrativa artesanal, na qual são utilizadas embarcações tradicionais para o deslocamento ao local da extração. Em cada pescaria foram utilizadas várias artes, tais como rede de espera, linha e anzol, rede de cerco, armadilhas. Foram identificadas 113 categorias taxonômicas de peixes (88), crustáceos (10) e moluscos (15), arranjadas em 77 tipos de pescados comercializados. A produção total no período foi de $345,2 \mathrm{t}$ ( $285.4 \mathrm{t} \mathrm{de}$ peixes, 39,2 t de invertebrados frescos e 20,6 t de invertebrados processados). Variações espaçotemporais da produção total desses pescados podem estar relacionadas à sazonalidade das condições meteorológicas, oceanográficas ou biológicas. A partir do preço da primeira comercialização, foi obtido um valor da primeira venda de $\mathrm{R} \$ 1279$ 881,63, sendo 71,3\% referentes à produção de peixes. Uma tabela de preço médio de cada recurso pesqueiro é fornecida. Contextualizando os dados pretéritos disponíveis, este trabalho pode ser considerado como uma referência para o futuro monitoramento da pesca na área.

Descriptors: Coastal fishery; Artisanal fishery; Fishing gear; Sale value; Northeast Brazil.

Descritores: Pesca costeira; Pesca artesanal; Arte de pesca; Preço de comercialização; Nordeste do Brasil.

\section{INTRODUCTION}

Todos os Santos Bay (12.61-13.13ㅇ / 38.45$\left.38.82^{\circ} \mathrm{W}\right)$, one of the most important waterways in Brazil $\left(1,100 \mathrm{~km}^{2}\right)$, is a complex ecosystem with brackish and marine waters, small internal bays, many islands, reefs, rivers, estuaries, mangroves, and rain forest, and has been a protected environmental area since June, 051999 in accordance with state law $\mathrm{n}^{\circ}$ 7595 (GOVERNO DA BAHIA, 2007). Thirteen towns, including Salvador (capital of Bahia State), the ports of Salvador and Aratu, the Aratu naval base, chemical and oil terminals, an oil refinery, and small oil fields are also located on Todos os Santos Bay. The northern portion of the bay lies within the area of four municipalities (Madre de Deus, São Francisco do Conde, Salvador and Candeias), which have been under the direct influence of the oil terminal (Madre de Deus) and the PETROBRAS oil refinery Refinaria Landulpho Alves Mataripe - RLAM (São Francisco do Conde) since 1949. There are thus many sources of anthropogenic pollution such as sewage disposal and industrial waste, the latter consisting mainly of oil refinery effluents. 
According to Wake's review (2005) on the ecological impacts of oil refineries on the aquatic environment, there have been many studies concerning the lethal toxicity of refinery effluent, but few studies on the sub-lethal effects. The author pointed out the need for sub-lethal effect studies, especially because the refinery effluents are cleaner now and are more likely to be having sub-lethal rather than lethal effects. The author also pointed out the need for field studies to document the sub-lethal effects of pollutants on the growth and recruitment of aquatic organisms.

While it may be difficult to document individual effects on particular species, it might be possible to examine existing data streams to infer effects due to pollutants. For example, the variability of the fishery production may be a measure of the sublethal effects of the oil effluent on the community or population, through the analysis of the variability in species diversity and abundance.

In this context, the aim of this study is to characterize the fishery activities in the area under the influence of the oil refinery and the oil terminal, between September 2003 and June 2005. The catch compositions, their variation from locality to locality and over the months, and the different fishery techniques employed are described. This investigation was conducted within the scope of the "Environmental Monitoring Program of the Estuarine Area near the RLAM Refinery" coordinated by Cenpes/Petrobras in partnership with IOUSP - Instituto Oceanográfico da Universidade de São Paulo (Oceanographic Institute of the University of São Paulo). The purpose of this program was to describe the estuarine region around the oil refinery RLAM in terms of the physical, chemical, and biological aspects of the water and the sediment.

Fishing in the northern portion of Todos os Santos bay, as well as the fisheries on the coast of the state of Bahia, could be described as a typical smallscale artisanal fishery (DIAS-NETO; DORNELLES, 1996), providing food and livelihood for the local community. Although the northern sector of Todos os Santos bay is not considered an important region for the fish trade, this activity is an alternative source of income for the poorer sectors of the community, either temporarily or part-time (ALMEIDA, 1996, unpublished); SILVA, 1996, unpublished); GIANNINI, 2000 (unpublished).

According to the Madre de Deus city hall, depending on the political-economical context, fishery resources can serve as both food supplement and source of income (GIANNINI, 2000 (unpublished). Local fishery resources from estuaries, mangroves, inter-tidal zones, and reefs are exploited. They have been sold locally within the communities or by traders in the larger neighboring towns such as Salvador, the capital of the state and an international tourist center (GIANNINI, 2000, unpublished).

The assessment, monitoring, and enforcement of the fishery resources and fishery activities are very important for conservation and management. However, according to Giannini (2000, unpublished)), the information on fisheries required for a detailed diagnosis was not available for the Madre de Deus island area or for the state of Bahia as a whole. In addition to the gaps in basic and applied studies, the few research results available are grey literature. This is true of the Brazilian coastal artisanal fisheries as a whole, which need studies on stock assessment as a support for the national policy (VASCONCELLOS et al., 2007).

\section{Material and Methods}

Data on daily total catch were obtained by tabulating data forms from local fishermen as well as from 16 monitoring visits by researchers carried out at six fishing landing sites or fishing grounds, between September 2003 and June 2005. One additional site was included in the second year (September 2004 June 2005) (Fig. 1). Those sites may be considered as capture locations due the limited operational range of the traditional vessels involved.

The local fishermen were trained for collecting scientific data on the forms, supplemented by their fishing knowledge. The fieldwork was supervised by a researcher and coordinated by the fishing association of Madre de Deus municipality working with a team of seven local fishermen, trained to collect data. During the sampling period, these fishermen were first trained, and then meetings were held monthly or every two months to monitor, evaluate, and review the form filling and to correct the identification of the organisms, for the purpose of maintaining confidence in the data.

Data registered on the forms were: name of the fisherman or fisherwoman; location, date and time of the fishing activity; name and type of the vessel; type of fishing gear employed; name, biomass, and first sale value of each resource.

Catches of fish, crustaceans and mollusks are expressed in biomass, which is the nominal weight at the time of capture, or in gutted weight in the case of some crustaceans and mollusks. A mass (kg) conversion table for the various trading units was made in order to calculate the total production, mainly for crustaceans and mollusks (Table 1). This conversion was based on the biomass provided and used by the fishermen. Data on total production of fish, crustaceans, and mollusks were calculated monthly, for each location. Data from Passé were excluded from the temporal comparative analyses because they did not cover the whole monitoring period. 


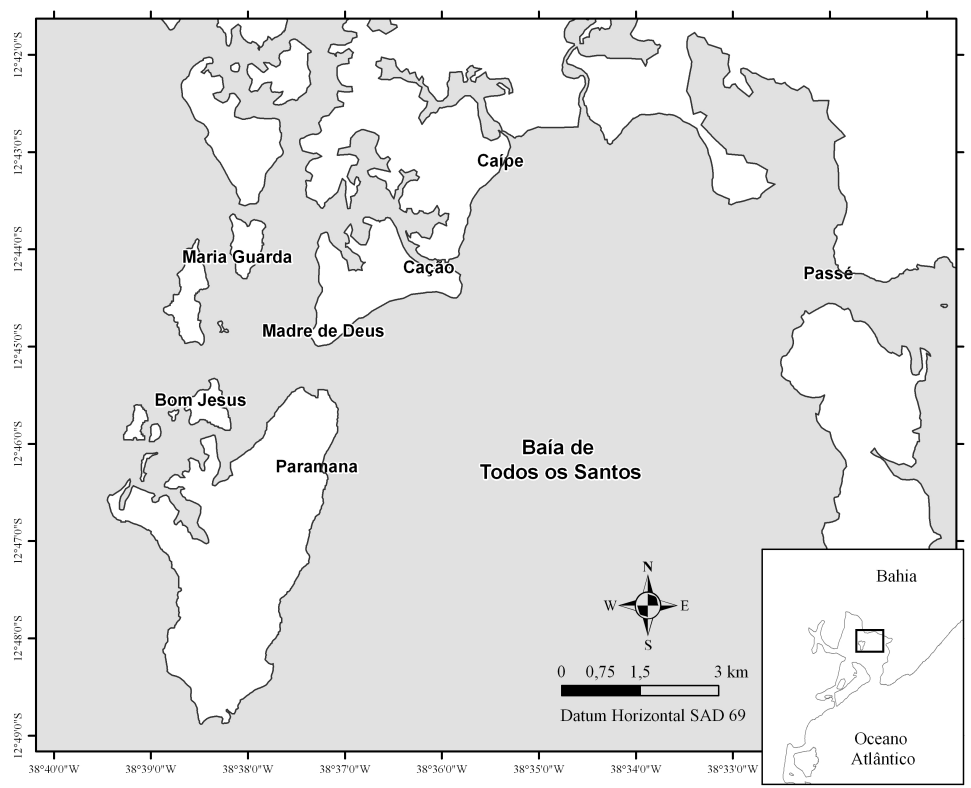

Fig. 1. Map of northern Todos os Santos bay, Brazil showing the six fishing landing sites or fishing grounds.

Table 1. Metric unit conversion of the local sale units of the fishery resources in northern Todos os Santos bay, Brazil

\begin{tabular}{|c|c|c|c|c|c|c|}
\hline & bucket (8 1) & a hundred & rope $(\mathrm{n}=10)$ & a dozen & can (18 l) & liter \\
\hline \multicolumn{7}{|l|}{ CRUSTACEANS } \\
\hline Ghost crab & & & $1.3 \mathrm{~kg}$ & & & \\
\hline Land crab & & & $1.1 \mathrm{~kg}$ & $2.0 \mathrm{~kg}$ & & \\
\hline Mangrove crab & & & $1.2 \mathrm{~kg}$ & $1.2 \mathrm{~kg}$ & & \\
\hline Swimcrab & $0.2 \mathrm{~kg} *$ & & $0.6 \mathrm{~kg}$ & $0.6 \mathrm{~kg}$ & $0.5 \mathrm{~kg}^{*}$ & \\
\hline \multicolumn{7}{|l|}{ MOLLUSKS } \\
\hline American yellow cockle & $6.5 \mathrm{~kg}$ & & & $0.1 \mathrm{~kg} *$ & $17 \mathrm{~kg}$ & \\
\hline Ark & $0.33 \mathrm{~kg} *$ & & & & $1 \mathrm{~kg} *$ & \\
\hline Brazilian chank & $0.33 \mathrm{~kg} *$ & & & & $1 \mathrm{~kg} *$ & \\
\hline Conch, melongena & & & & & $1.1 \mathrm{~kg} *$ & \\
\hline Mussel & $0.33 \mathrm{~kg} *$ & & & $0.1 \mathrm{~kg} *$ & $1 \mathrm{~kg} *$ & $0.07 \mathrm{~kg} *$ \\
\hline Oyster, penshell & $0.4 \mathrm{~kg} *$ & & & & $1.2 \mathrm{~kg} *$ & \\
\hline Stout tagelus & & & & $0.1 \mathrm{~kg} *$ & $1 \mathrm{~kg} *$ & $0.1 \mathrm{~kg} *$ \\
\hline Thick lucine & & $0.83 \mathrm{~kg} *$ & & $0.1 \mathrm{~kg} *$ & & $0.1 \mathrm{~kg} *$ \\
\hline West Indian pointed venus & $0.33 \mathrm{~kg} *$ & & & & $1 \mathrm{~kg} *$ & \\
\hline \multicolumn{7}{|l|}{ FISH } \\
\hline Common snook & & & & & $6 \mathrm{~kg}$ & \\
\hline Herrings, anchovies & & & & & $12 \mathrm{~kg}$ & \\
\hline Miscellaneous fish & & & & & $12 \mathrm{~kg}$ & \\
\hline Mojarras & & & & & $8 \mathrm{~kg}$ & \\
\hline Shrimp eel & & & & & $3 \mathrm{~kg}$ & \\
\hline
\end{tabular}

* processed product

A list of local names and taxonomic identification of fishes, crustaceans, and mollusks was prepared. Organisms were identified by the authors of the present paper according to specific taxonomy guides (FIGUEIREDO, 1977; FIGUEIREDO; MENEZES, 1978, 1980, 2000; MENEZES; FIGUEIREDO, 1980, 1985; RIOS, 1994; MELO,
1996, 1998; MENEZES et al., 2003). The validity of species was based on Eschmeyer and Fong (2008), ITIS (2008) and Conchas do Brasil (2008). A reference collection (56 fish resources) named as the PROMARLAM series was deposited in the biological collections of the Oceanographic Institute of the University of São Paulo. 


\section{Results}

Observations during the monitoring visits to the study area indicated a lack of cooling and freezing facilities on the boats, in the fish market of Madre de Deus, and in the three fishery organizations, demonstrating the poor infrastructure of fishing activities. The fishery catch is transported to the landing sites by boat and sold on the spot, on the street, or in the market. Thus, fishing activity is limited by distance due to the availability of boats, and the transit time due to the perishability of the products.

Catch data, based on 24,218 forms, showed that fishing activity was performed by 1,429 fishermen and fisherwomen, most of them $(90 \%)$ only working at one landing site. Fishing grounds were reached mainly by canoes (61\%), small boats (9\%), or on foot $(21 \%)$; however, these vessels are only used for locomotion, not as fishing platforms. The canoes (3-5 m. long) are wooden vessels, propelled with paddles, some of them with an auxiliary sail, usually operated by one or two fishermen. The boats (4-6 m. long) are fitted with a low-power inboard engine (11 HP or less), and usually operated by two or three fishermen. Fishing activity takes place in the near-shore waters due to the range of the traditional artisanal vessels, and also along the intertidal zones, during the morning (59\%).
A total of 47 fishing gear names were registered, classified according to the type of fishing for which they were used, in addition to free diving. A brief description of each gear or set of gear is presented in Table 2. One to five kinds of gear were used in each fishing activity, characteristic of multiple gear fishing. Gathering by hand or with simple hand implements (spoon, axe, hatchet, and shovel) was the most frequent method employed (occurrence of $31 \%$ ), mainly for gathering bivalve species on foot in the intertidal zones of two sites (Caípe and Cação). Other common fishing techniques were fixed gillnet (passive gear) and handline and longline fishing (active gear). Line fishing was mainly used in Bom Jesus and Maria da Guarda islands, and fixed gillnets in Paramana and Passé. A local kind of encircling net known as abalo, a kind of passive-active gear, was mainly used in Passé and Madre de Deus Island; in this method of capture, the paddle is hit on the water (or on the bottom of the boat) to make a noise and to frighten the fish towards the surrounding net and thus get entangled in it. In addition, a range of net types was applied, including beach seine nets, traps, cast nets, luring, and encircling nets. Free diving was usually performed by only one fisherman (averaging two-minute duration) for handcapture of some mollusks (fighting conch - peguari or ark - sambá) and lobsters, or for hunting lobsters and some fishes with a spear.

Table 2. Types of fishing gear used by artisanal fishers in northern Todos os Santos bay, Brazil.

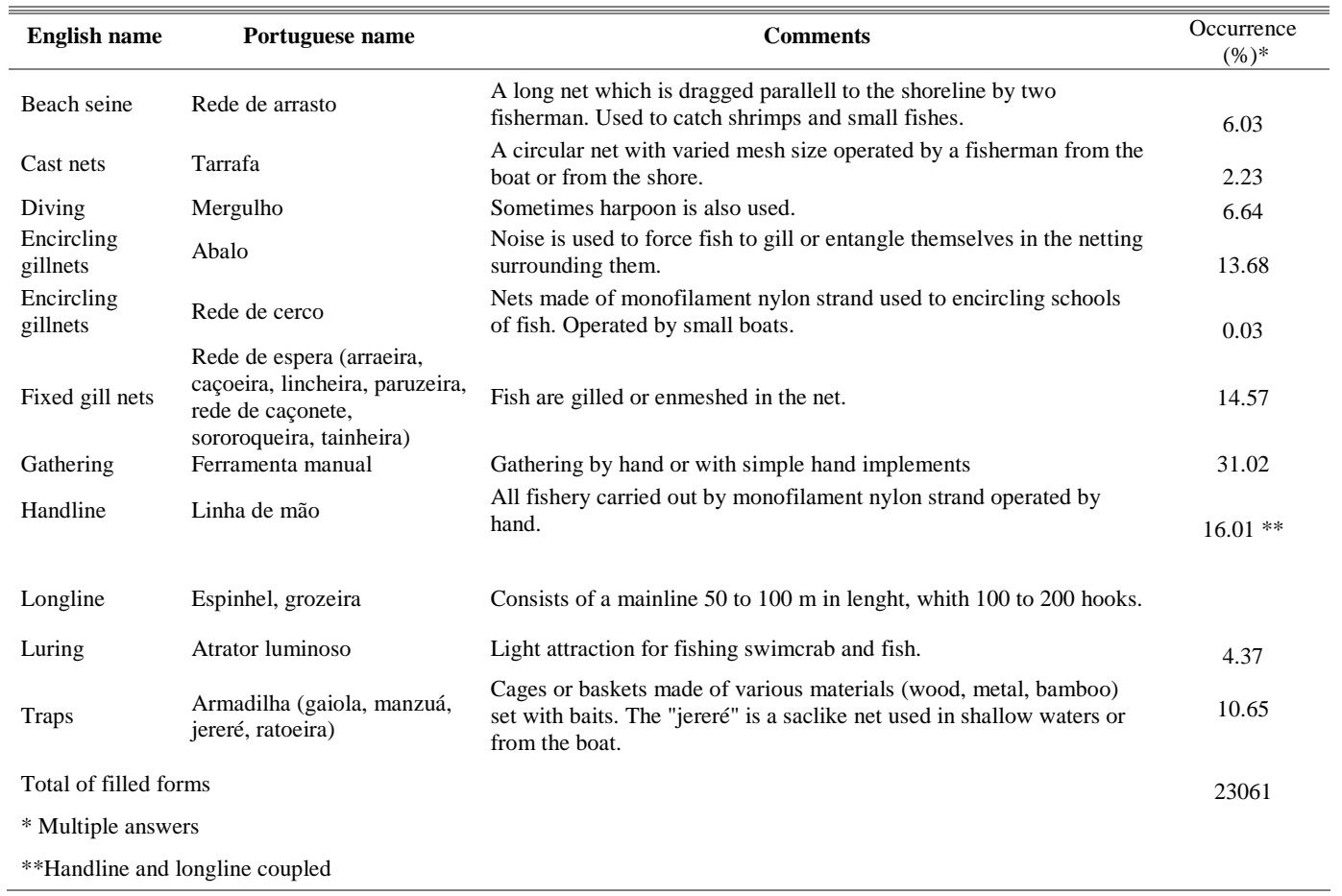


Species

An estimate of 113 taxa (species or genera), grouped into 77 aggregated fishing resources, including 88 fishes, 10 crustaceans, and 15 mollusks, was made for the study area (Table 3 ). These include pelagic, bentho-pelagic, benthic, intertidal, and coralreef species. The resources of high catch biomass were small pelagic fishes, such as herrings (Clupeidae) and anchovies (Engraulidae), several species of mullet (Mugilidae), and several species of ray and skate. Other species are included among the representative bentho-pelagic resources: jack (Carangidae), mackerel (Scombridae), and weakfishes (Sciaenidae); and among the benthic or demersal resources: catfish, shrimp, swimming-crab, ghost crab, land crab, oyster, snappers (Lutjanidae), and seabream (Sparidae).

\section{Catches}

A total of 345.2 tonnes of fishery resources was produced during the monitoring period (22 months), composed of 285.4 tonnes of fishes, 39.2 tonnes of fresh invertebrates, and 20.6 tonnes of processed invertebrates.
Monthly, the total fish production ranged from 8 tonnes (February 2005) to 19 tonnes (February 2004) (Fig. 2). The highest production occurred in the first quarter (summer) of 2004; the fourth quarter (spring) of 2003 and 2004 showed the same trend, with a decrease in production between October and November, and an increase in December. The most frequently captured fish were rays, mullet, herrings and anchovies. Other representative resources were catfish, horse-eyed, jack (cabeçudo), lane snapper (vermelho), weakfishes (pescada), serra Spanish mackerel (sororoca), and western Atlantic sea-bream (sambuio). The production of rays was primarily responsible for the monthly variation in total production. There was an alternation between the production of mullet, and that of herrings and anchovies. The production of mullet was higher during the fourth quarter (spring) of 2003 and first quarter (summer) of 2004, the production of herrings and anchovies was higher from the second (fall) to fourth (spring) quarters of 2004 (Fig. 2). During the study period, the highest production occurred in Bom Jesus, and the lowest in Caípe (Fig. 3), with biomass variation of the most important fish.

Table 3. Species composition of fishery resources (scientific and common names) caught between September 2003 and June 2005 , in northern Todos os Santos bay, Brazil.

\begin{tabular}{|c|c|c|c|c|c|}
\hline ENGLISH NAME & LOCAL NAME & $\begin{array}{c}\text { OTHER ENGLISH } \\
\text { NAMES }\end{array}$ & $\begin{array}{l}\text { OTHER LOCAL } \\
\text { NAMES }\end{array}$ & SCIENTIFIC NAME & FAMILY \\
\hline CRUSTACEANS & CRUSTÁCEOS & & & & \\
\hline Ghost crab & Caranguejo & - & - & Ucides cordatus & Ocypodidae \\
\hline Land crab & Guaiamu & Giant land crab & - & Cardisoma guanhumi & Gercacinidae \\
\hline Lobster & Lagosta & Spiny loster & Lagosta verde & Palinurus spp. & Palinuridae \\
\hline \multirow{2}{*}{ Mangrove crab } & Aratu & Mangrove root crab & - & Goniopsis cruentata & Grapsidae \\
\hline & & Mangrove tree crab & - & Aratus pisonii & Sesarmidae \\
\hline Shrimp ${ }^{1}$ & Camarão & - & - & - & Penaeidae \\
\hline Small shrimp & $\begin{array}{l}\text { Camarão } \\
\text { pequeno }\end{array}$ & Atlantic seabob & - & Xiphopenaeus kroyeri & Penaeidae \\
\hline \multirow[t]{4}{*}{ Swimcrab $^{2}$} & Siri & Blotched swimming crab & \multirow{4}{*}{$\begin{array}{l}\text { Siri bóia, siri branco, } \\
\text { siri canxaga, siri } \\
\text { regateira, siri mangue }\end{array}$} & Portunus spinimanus & Portunidae \\
\hline & & Dana swimcrab & & Callinectes danae & Portunidae \\
\hline & & Shelling crab & & Callinectes ornatus & Portunidae \\
\hline & & Blunttooth swimcrab & & Callinectes bocourti & Portunidae \\
\hline MOLLUSKS & MOLUSCOS & & & & \\
\hline $\begin{array}{l}\text { American yellow } \\
\text { cockle }\end{array}$ & Rala-côco & - & - & Trachicardium muricatum & Cardiidae \\
\hline Ark & Sambá & Incongruous ark & - & Anadara brasiliana & Arcidae \\
\hline Brazilian chank & Tapu & - & - & Turbinella laevigata & Turbinellidae \\
\hline \multirow[t]{2}{*}{ Conch, melongena } & Peguari & Fighting conch & - & Strombus pugilis & Strombidae \\
\hline & & Giant hairy melongena & - & Pugilina morio & Melonginidae \\
\hline Mussel & Sururu & - & Sururu-de-coroa & $\begin{array}{l}\text { Mytella spp., } \\
\text { Mytella charruana }\end{array}$ & Mytilidae \\
\hline Octopus & Polvo & - & - & Octopus spp. & Octopodidae \\
\hline \multirow[t]{2}{*}{ Oyster, penshell } & Ostra & Pacific cupped oyster & Ostra de mangue & $\begin{array}{l}\text { Crassostrea spp., } \\
\text { Crassostrea rhizophorae }\end{array}$ & Ostreidae \\
\hline & & Half-naked penshell & Ostra de palma & Atrina seminuda & Pinnidae \\
\hline Squid & Lula & - & - & Loligo spp. & Loliginidae \\
\hline Stout tagelus & Mapele & - & - & Tagelus plebeius & Solecurtidae \\
\hline Thick lucine & Lambreta & - & - & Lucina pectinata & Lucinidae \\
\hline $\begin{array}{l}\text { West Indian } \\
\text { pointed venus }\end{array}$ & Papa-fumo & - & - & Anomalocardia brasiliana & Veneridae \\
\hline
\end{tabular}


Table 3. Continuation

\begin{tabular}{|c|c|c|c|c|c|}
\hline ENGLISH NAME & LOCAL NAME & $\begin{array}{l}\text { OTHER ENGLISH } \\
\text { NAMES }\end{array}$ & $\begin{array}{l}\text { OTHER LOCAL } \\
\text { NAMES }\end{array}$ & SCIENTIFIC NAME & FAMILY \\
\hline CRUSTACEANS & CRUSTÁCEOS & & & & \\
\hline Acoupa weakfish & Pescada-amarela & - & - & Cynoscion acoupa & Sciaenidae \\
\hline African pompano & Aracanguira & - & - & Alectis ciliaris & Carangidae \\
\hline \multirow{2}{*}{$\begin{array}{l}\text { Angelfish, } \\
\text { Spadefish }\end{array}$} & Paru & Atlantic spadefish & Paru-branco & Chaetodipterus faber & Ephippidae \\
\hline & & French angelfish & Paru-cagão & Pomacanthus paru & Pomacanthidae \\
\hline Atlantic bigeye & Olho-de-vidro & - & - & Priacanthus arenatus & Priacanthidae \\
\hline Atlantic bumper & Garapau & - & Garapau-fava & Chloroscombrus chrysurus & Carangidae \\
\hline Barracuda & Bicuda & - & - & Sphyraena spp. & Sphyraenidae \\
\hline Barred grunt & Corvina-amarela & - & - & Conodon nobilis & Haemulidae \\
\hline Bluewing searobin & Voador & - & Cabrinha & Prionotus punctatus & Triglidae \\
\hline Burrfish & Baiacu-espinho & Web burrfish & - & Chilomycterus antillarum & Diodontidae \\
\hline Chere-chere grunt & Coró & Grunt & $\begin{array}{l}\text { Coró branco, coró de } \\
\text { pedra }\end{array}$ & $\begin{array}{l}\text { Pomadasys spp., Haemulon } \\
\text { steindachneri }\end{array}$ & Haemulidae \\
\hline Cobia & Bijupirá & - & - & Rachycentron canadum & Rachycentridae \\
\hline Common snook & Robalo & - & $\begin{array}{l}\text { Robalo branco, } \\
\text { robalo-flecha, } \\
\text { robalinho }\end{array}$ & Centropomus undecimalis & Centropomidae \\
\hline Doctorfish & Barbeiro & Ocean surgeon & - & Acanthurus bahianus & Acanthuridae \\
\hline Dog snapper & Dentão & - & - & Lutjanus spp., Lutjanus jocu & Lutjanidae \\
\hline Fat snook & Robalo-pena & - & - & Centropomus parallelus & Centropomidae \\
\hline \multirow{4}{*}{$\begin{array}{l}\text { Flounder, sole, } \\
\text { tonguefish }\end{array}$} & Linguado & Sole & Aramaçã & Achirus spp. & Achiridae \\
\hline & & Flounder & Aramaçã & Bothus spp. & Bothidae \\
\hline & & Tonguefish & Aramaçã & Symphurus spp. & Cynoglossidae \\
\hline & & Flounder & Aramaçã & $\begin{array}{l}\text { Citharichthys spp., Syacium } \\
\text { spp., Paralichthys spp. }\end{array}$ & Paralichthydae \\
\hline Giant grouper & Mero & - & - & Epinephelus itajara & Serranidae \\
\hline Grey snapper & Caranha & - & Acaranha & Lutjanus griseus & Lutjanidae \\
\hline \multirow{4}{*}{$\begin{array}{l}\text { Grouper, seabass, } \\
\text { hamlet }\end{array}$} & Garoupa & - & - & Epinephelus spp. & Serranidae \\
\hline & & Coney seabass & - & Cephalopholis fulva & Serranidae \\
\hline & & Mutton hamlet & - & Alphestes afer & Serranidae \\
\hline & Badejo & - & $\begin{array}{l}\text { Badejo-amarelo, } \\
\text { badejo guba }\end{array}$ & Mycteroperca spp. & Serranidae \\
\hline \multirow[t]{2}{*}{ Halfbeak } & Agulha-branca & Ballyhoo halfbeak & - & Hemiramphus brasiliensis & Hemiramphidae \\
\hline & & Common halfbeak & - & Hyporamphus unifasciatus & Hemiramphidae \\
\hline \multirow[t]{4}{*}{$\begin{array}{l}\text { Herrings, } \\
\text { anchovies }\end{array}$} & Sardinha & Atlantic thread herring & $\begin{array}{l}\text { Pititinga, massambê, } \\
\text { xangó }\end{array}$ & Opisthonema oglinum & Clupeidae \\
\hline & & Anchovy & & Anchoa spp. & Engraulidae \\
\hline & & Zabaleta anchovy & & Anchovia clupeoides & Engraulidae \\
\hline & & Atlantic anchoveta & & Cetengraulis edentulus & Engraulidae \\
\hline \multirow[t]{3}{*}{ Jacks } & Cabeçudo & Blue runner & $\begin{array}{l}\text { Xáreu, xaréu amarelo, } \\
\text { chumberga, } \\
\text { cabeçudinho, } \\
\text { guaricema }\end{array}$ & Caranx crysos & Carangidae \\
\hline & & Horse-eye jack & & Caranx latus & Carangidae \\
\hline & Guaraiuba & - & - & Caranx spp. & Carangidae \\
\hline King mackerel & Cavala & - & Cavalinha & Scomberomorus cavalla & Scombridae \\
\hline Ladyfish & Obarana & - & - & Elops saurus & Elopidae \\
\hline Lane snapper & Vermelho & - & Ariacó & Lutjanus synagris & Lutjanidae \\
\hline Largehead hairtail & Espada & - & - & Trichiurus lepturus & Trichiuridae \\
\hline \multirow[t]{3}{*}{$\begin{array}{l}\text { Leatherjacket, } \\
\text { pompano }\end{array}$} & Solteira & Maracaibo leatherjacket & $\begin{array}{l}\text { Pampo, pampo } \\
\text { amarelo, dourado, } \\
\text { riate }\end{array}$ & Oligoplites palometa & Carangidae \\
\hline & & Atlantic leatherjacket & & Oligoplites saurus & Carangidae \\
\hline & & Pompano & & Trachinotus spp. & Carangidae \\
\hline Live sharksucker & Pegador & - & - & Echeneis naucrates & Echeneidae \\
\hline Lookdown & Peixe-galo & - & Galo bandeira & Selene spp., Selene vomer & Carangidae \\
\hline
\end{tabular}


Table 3. Continuation.

\begin{tabular}{|c|c|c|c|c|c|}
\hline $\begin{array}{l}\text { ENGLISH } \\
\text { NAME }\end{array}$ & LOCAL NAME & $\begin{array}{l}\text { OTHER ENGLISH } \\
\text { NAMES }\end{array}$ & $\begin{array}{l}\text { OTHER LOCAL } \\
\text { NAMES }\end{array}$ & SCIENTIFIC NAME & FAMILY \\
\hline CRUSTACEANS & CRUSTÁCEOS & & & & \\
\hline \multirow[t]{6}{*}{ Mojarra } & Carapeba rajada & Caitipa mojarra & \multirow{2}{*}{$\begin{array}{l}\text { Carapeba listrada, } \\
\text { carapeba riscada }\end{array}$} & Diapterus rhombeus & Gerreidae \\
\hline & & Irish mojarra & & Diapterus auratus & Gerreidae \\
\hline & Carapeba & Brazilian mojarra & Carapeba-branca, & Eugerres brasilianus & Gerreidae \\
\hline & & & carapeba de lama & & \\
\hline & Carapicu & Jenny mojarra & \multirow{2}{*}{$\begin{array}{l}\text { Carapicu branco, } \\
\text { carapicu flecha }\end{array}$} & Eucinostomus gula & Gerreidae \\
\hline & & Silver mojarra & & Eucinostomus argenteus & Gerreidae \\
\hline Moray & Caramuru & - & Moréia & Gymnothorax spp. & Muraenidae \\
\hline Mullets & Tainha & Lebranche mullet & $\begin{array}{l}\text { Chaverta, curimã, } \\
\text { saúna }\end{array}$ & Mugil spp., Mugil liza & Mugilidae \\
\hline Mutton snapper & Cioba & - & - & Lutjanus analis & Lutjanidae \\
\hline \multirow[t]{2}{*}{ Needlefish } & Agulha & Atlantic needlefish & - & Strongylura marina & Belonidae \\
\hline & & Timucu & - & Strongylura timucu & Belonidae \\
\hline Pacuma toadfish & Pocomom & - & - & Batrachoides surinamensis & Batrachoididae \\
\hline Parrot fish & Budião & - & $\begin{array}{l}\text { Budião batata, budião } \\
\text { manteiga }\end{array}$ & Scarus spp., Sparisoma spp. & Scaridae \\
\hline Porkfish & Salema & - & - & Anisotremus virginicus & Haemulidae \\
\hline Puffers & Baiacu & $\begin{array}{l}\text { Checkered puffer, } \\
\text { bandtail puffer }\end{array}$ & $\begin{array}{l}\text { Baiacu mangue, } \\
\text { baiacu feiticeiro, } \\
\text { baiacu bundinha, } \\
\text { baiacu facho, baiacu } \\
\text { guimba }\end{array}$ & $\begin{array}{l}\text { Sphoeroides spp., Sphoeroides } \\
\text { testudineus, S. splengleri }\end{array}$ & Tetraodontidae \\
\hline \multirow[t]{3}{*}{ Rays } & Arraia & Stingray & $\begin{array}{l}\text { Arraia-branca, arraia- } \\
\text { amarela }\end{array}$ & Dasyatis spp. & Dasyatidae \\
\hline & & Butterfly ray & Arraia-manteiga & Gymnura spp. & Gymnuridae \\
\hline & & Guitarfish & Viola & Rhinobatos spp. & Rhinobatidae \\
\hline Sailor's grunt & Cambuba & - & $\begin{array}{l}\text { Coró branco, coró de } \\
\text { pedra }\end{array}$ & Haemulon parra & Haemulidae \\
\hline \multirow[t]{2}{*}{ Scad } & Xixarro & - & - & Decapterus spp. & Carangidae \\
\hline & & Bigeye scad & - & Selar crumenophthalmus & Carangidae \\
\hline \multirow[t]{3}{*}{ Sea catfish } & Bagre & Gafftopsail sea catfish & Bagre-branco & Bagre marinus & Ariidae \\
\hline & & Madamango sea catfish & Bagre-amarelo & Cathorops spixii & Ariidae \\
\hline & & Bressou sea catfish & Bagre-amarelo & Aspistor luniscutis & Ariidae \\
\hline $\begin{array}{l}\text { Serra Spanish } \\
\text { mackerel }\end{array}$ & Sororoca & - & - & Scomberomus brasiliensis & Scombridae \\
\hline \multirow[t]{2}{*}{ Sharks } & \multirow[t]{2}{*}{ Cação } & $\begin{array}{l}\text { Caribbean sharpnose } \\
\text { shark }\end{array}$ & Caçonete & Rhizoprionodon porosus & Carcharhinidae \\
\hline & & Nurse shark & Cação lixa & Ginglymostoma cirratum & $\begin{array}{l}\text { Gynglymostomat } \\
\text { idae }\end{array}$ \\
\hline Sheepshead porgy & Pena & - & - & Calamus penna & Sparidae \\
\hline Shrimp eel & Miroró & - & Miroró mirim, mirim & $\begin{array}{l}\text { Ophicthus spp., Ophicthus } \\
\text { gomesii }\end{array}$ & Ophichthydae \\
\hline Spotted eagle ray & Pintado & - & Raia-pintada & Aetobatus narinari & Myliobatidae \\
\hline Squirrelfish & Jaguaraça & - & - & Holocentrus adscensionis & Holocentridae \\
\hline Tarpon & Caramuru pinho & - & - & Megalops atlanticus & Megalopidae \\
\hline Weakfish & Pescada & - & $\begin{array}{l}\text { Pescada-branca, } \\
\text { pirambeba }\end{array}$ & Cynoscion spp. & Sciaenidae \\
\hline $\begin{array}{l}\text { Western Atlantic } \\
\text { seabream }\end{array}$ & Sambuio & - & Bobó & Archosargus rhomboidalis & Sparidae \\
\hline $\begin{array}{l}\text { Whitemouth } \\
\text { croaker }\end{array}$ & Corvina & - & Corvina branca & Micropogonias furnieri & Sciaenidae \\
\hline $\begin{array}{l}\text { Yellowtail } \\
\text { amberjack }\end{array}$ & Arabaiana & - & - & Seriola lalandi & Carangidae \\
\hline$\underset{(3)}{\text { Miscellaneous fish }}$ & Peixe misto ${ }^{(3)}$ & & & & \\
\hline
\end{tabular}




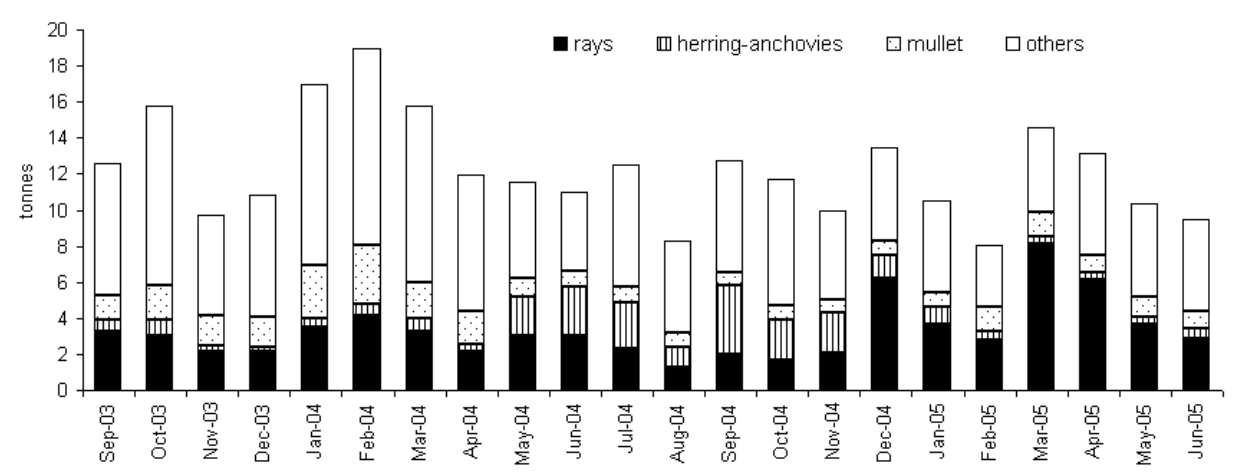

Fig. 2. Monthly fish production during the years 2003 - 2005, in northern Todos os Santos bay, Brazil.

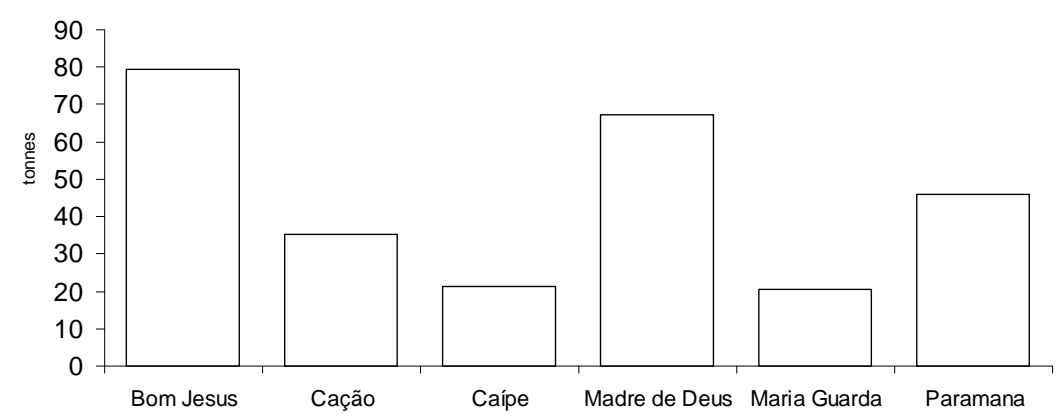

Fig. 3. Total fish production per site, during September 2003 - June 2005, in northern Todos os Santos bay, Brazil.

The total catch of fresh crustaceans ranged from 0.6 tonne in September 2003 and January 2005 to 3 tonnes in February 2004 (Fig. 4). The highest values were registered in the first (summer) and second (fall) quarters of 2004. There were noticeably lower catches toward the second half of the time series. Catches of shrimps and ghost crabs were primarily responsible for that trend. Total production of processed crustaceans, i.e., the swimming-crabs, was lower than that of the fresh ones, and did not show any trend, amounting approximately to 0.4 tonne monthly during the studied period (Fig. 5). In contrast to the crustacean production, the larger part $(87 \%)$ of the catch of mollusks was processed. The highest values were found during the third (winter) and fourth (spring) quarters of 2003, and the lowest, during the second (fall) and third (winter) quarters of 2004 (Fig. 6). This trend was due to the production of the West Indian oyster, pointed Venus (papa-fumo), and fighting conch (peguari). The American yellow cockle (rala-coco), the main fresh mollusk resource, showed the highest value during the fourth quarter (spring October) of 2003 and the third quarter (winter August) of 2004 (Fig. 7).
Fishing catches were sold at the landing spot or in the Madre de Deus market, the only market in the study region. The first value of this catch amounted to US\$ 614,995.00, around US\$ 28,000.00 per month. Fish resources were responsible for $71.3 \%$ (US $\$ 438,491.44$ ) of the total revenue, crustaceans for $20.4 \%$, and mollusks for $8.4 \%$. The average price of the fish resources varied from US\$ $0.78 / \mathrm{kg}$ for miscellaneous fish to US\$ $3.18 / \mathrm{kg}$ for fat snook (robalo-pena). Herring and anchovies are among the cheapest fishes; rays are of intermediate values; and snooks and snappers are the most highly valued fishes (Table 4). The table of the first sale value (US\$) of crustacean and mollusk resources showed that average value of processed invertebrates was higher than that of the fresh ones (Table 5). Among fresh crustaceans, lobster showed the highest value (US\$ 5.53/kg) while the ghost crab (caranguejo) and the mangrove-crab (aratu) the lowest one; shrimp also had a high price (US\$ 3.90/kg). Overall, the average price of processed crustaceans was US\$ $4.00 / \mathrm{kg}$, and the processed mollusks reached higher values than the fresh ones, with the exception of squid and octopus. 


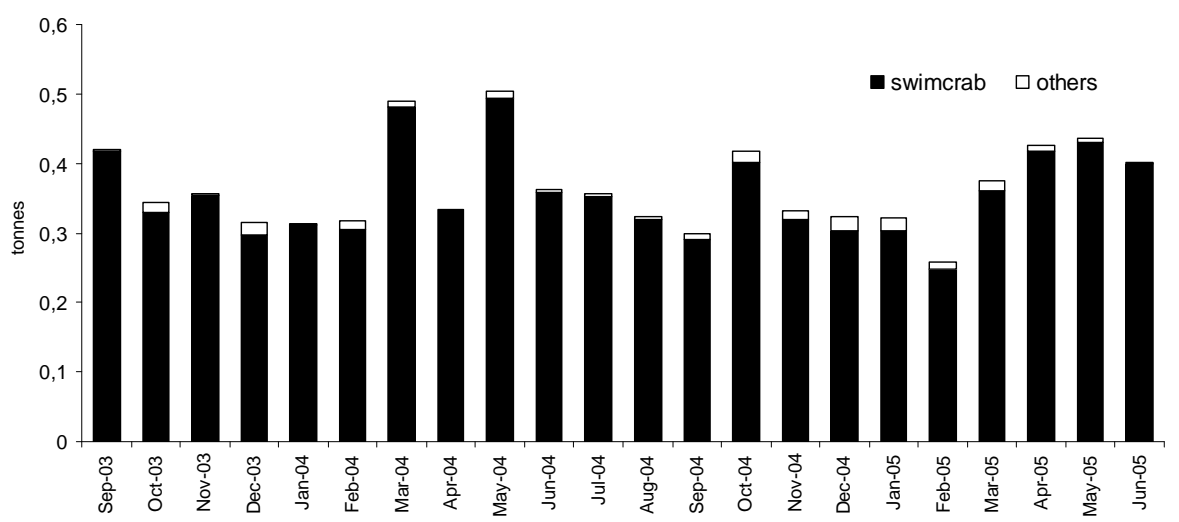

Fig. 5. Monthly processed crustacean production during the years 2003 - 2005, in northern Todos os Santos bay, Brazil.

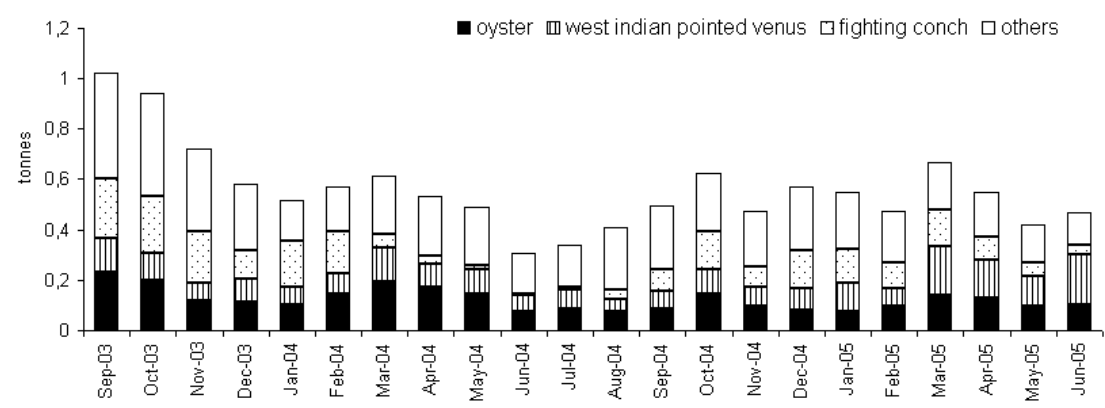

Fig. 6. Monthly processed mollusks production during the years 2003 - 2005, in northern Todos os Santos bay, Brazil.

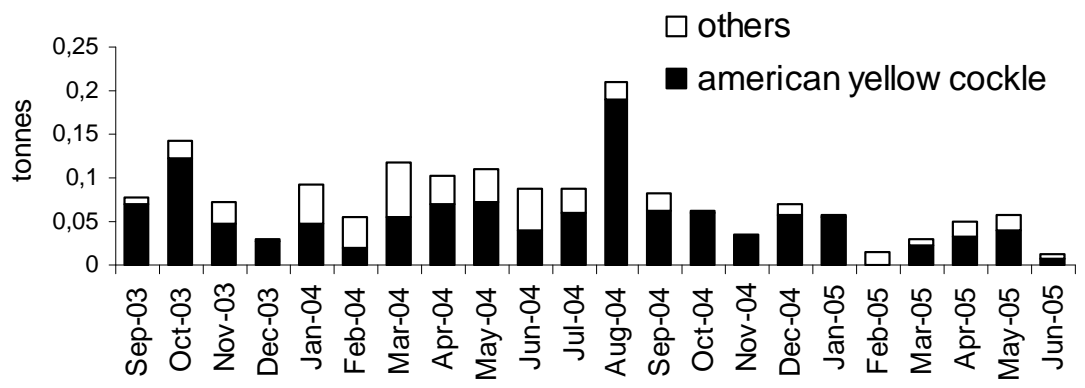

Fig. 7. Monthly fresh mollusks production during the years 2003 - 2005, in northern Todos os Santos bay, Brazil. 
Table 4. First sale value of fish resources (US\$/ kg) and total catch $(\mathrm{kg})$ in northern Todos os Santos bay, Brazil.

\begin{tabular}{|c|c|c|}
\hline Fish & US\$/kg & $\begin{array}{c}\text { Total Catch } \\
\text { (kg) }\end{array}$ \\
\hline Acoupa weakfish & 2.54 & 425.5 \\
\hline African pompano & 2.35 & 190.5 \\
\hline Angelfish and Spadefish & 1.47 & 2424.5 \\
\hline Atlantic bigeye & 2.04 & 358.5 \\
\hline Atlantic bumper & 1.01 & 3949.5 \\
\hline Barracuda & 2.04 & 1176.0 \\
\hline Barred grunt & 2.03 & 143.0 \\
\hline Bluewing searobin & 0.94 & 389.3 \\
\hline Brazilian mojarra & 1.41 & 5410.8 \\
\hline Burrfish & 1.34 & 63.5 \\
\hline Caitiba mojarra, Irish mojarra & 1.85 & 1039.8 \\
\hline Chere-chere grunt & 1.06 & 5791.1 \\
\hline Cobia & 2.71 & 1251.0 \\
\hline Common snook & 3.05 & 6317.2 \\
\hline Doctorfish & 1.12 & 93.8 \\
\hline Dog snapper & 3.07 & 2258.4 \\
\hline Fat snook & 3.18 & 2033.0 \\
\hline Flounder, sole, tonguefish & 1.50 & 939.2 \\
\hline Gafftopsail sea catfish & 0.84 & 9838.7 \\
\hline Giant grouper & 2.65 & 454.5 \\
\hline Grey snapper & 2.83 & 709.0 \\
\hline Grouper, seabass, hamlet & 1.82 & 243.0 \\
\hline Halfbeak & 1.54 & 424.5 \\
\hline Herring, anchovies & 0.82 & 25620.9 \\
\hline Jacks & 2.16 & 13102.0 \\
\hline Jenny mojarra, Silver mojarra & 1.03 & 1536.2 \\
\hline King mackerel & 2.11 & 2132.3 \\
\hline Ladyfish & 1.38 & 460.0 \\
\hline Lane snapper & 2.70 & 9698.7 \\
\hline Largehead hairtail & 1.14 & 1567.0 \\
\hline Leatherjacket and pompano & 2.29 & 3817.4 \\
\hline Lebranche mullet & 1.76 & 29642.6 \\
\hline Live sharksucker & 0.85 & 13.5 \\
\hline Lookdown & 2.69 & 527.5 \\
\hline Miscellaneous fish & 0.78 & 929.3 \\
\hline Miscellaneous sea catfish & 1.26 & 3643.8 \\
\hline Moray & 1.58 & 2652.2 \\
\hline Mutton snapper & 2.59 & 782.0 \\
\hline Needlefish & 1.44 & 647.8 \\
\hline Pacuma toadfish & 1.36 & 926.1 \\
\hline Parrot fish & 1.47 & 2220.0 \\
\hline Porkfish & 2.88 & 15.0 \\
\hline Puffers & 1.51 & 1471.2 \\
\hline Rays & 1.21 & 72538.0 \\
\hline Sailor's grunt & 1.26 & 4470.5 \\
\hline Scad & 1.17 & 600.0 \\
\hline Serra Spanish mackerel & 1.93 & 9441.5 \\
\hline Sharks & 2.20 & 2400.0 \\
\hline Sheepshead porgy & 2.24 & 487.3 \\
\hline Shrimp eel & 1.11 & 2891.5 \\
\hline Spotted eagle ray & 1.89 & 9926.0 \\
\hline Squirrelfish & 0.80 & 9.0 \\
\hline Tarpon & 1.63 & 147.0 \\
\hline Unidentified grouper & 2.63 & 102.6 \\
\hline Unidentified jack & 1.69 & 338.0 \\
\hline Weakfish & 2.12 & 8027.2 \\
\hline Western Atlantic seabream & 1.42 & 8232.9 \\
\hline Whitemouth croaker & 1.97 & 2911.0 \\
\hline Yellowtail amberjack & 1.73 & 45.0 \\
\hline Average $=1.56$ & & 269897.3 \\
\hline
\end{tabular}

Table 5. First sale value of crustaceans and mollusks (US\$/ $\mathrm{kg}$ ) and total catch $(\mathrm{kg})$ in northern Todos os Santos bay, Brazil.

\begin{tabular}{|c|c|c|c|c|}
\hline & \multicolumn{2}{|c|}{ Fresh } & \multicolumn{2}{|c|}{ Processed } \\
\hline & $\begin{array}{c}\text { First } \\
\text { value } \\
\text { (US\$/kg) }\end{array}$ & $\begin{array}{c}\text { Total } \\
\text { catch } \\
(\mathrm{kg})\end{array}$ & $\begin{array}{l}\text { First value } \\
\text { (US\$/kg) }\end{array}$ & $\begin{array}{c}\text { Total } \\
\text { catch } \\
(\mathrm{kg})\end{array}$ \\
\hline \multicolumn{5}{|l|}{ Crustacean } \\
\hline Ghost crab & 1.46 & 9506.9 & 3.96 & 49.2 \\
\hline Land crab & 1.83 & 2673.4 & 4.00 & 6.0 \\
\hline Lobster & 5.53 & 1782.4 & & \\
\hline Mangrove crab & 1.43 & 619.2 & 3.74 & 145.1 \\
\hline Shrimp & 3.90 & 8528.1 & & \\
\hline Small shrimp & 2.16 & 804,0 & & \\
\hline Soft crab & 3.68 & 553.1 & 4.80 & 0.6 \\
\hline Swimcrab & 2,00 & 6804.4 & 4.40 & 6363.9 \\
\hline Average & 2.56 & & 4.38 & \\
\hline \multicolumn{5}{|l|}{ Mollusks } \\
\hline $\begin{array}{l}\text { American yellow } \\
\text { cockle }\end{array}$ & 0.27 & 1201.1 & 3.01 & 211.6 \\
\hline Ark & 1.50 & 24,0 & 4.84 & 2267.4 \\
\hline Brazilian chank & & & 3.75 & 54.9 \\
\hline Conch, melongena & & & 4.82 & 2041.1 \\
\hline Mussel & 0.72 & 98.5 & 3.51 & \\
\hline Octopus & 4.43 & 13,0 & & 1569.1 \\
\hline Oyster, penshell & 1.98 & 12,0 & 3.22 & 2400.3 \\
\hline Squid & 4.01 & 237.8 & & \\
\hline Stout tagelus & 3.46 & 3.1 & 6.41 & 14.4 \\
\hline Thick lucine & 0.65 & 38.5 & 6.59 & 528.8 \\
\hline $\begin{array}{l}\text { West Indian pointed } \\
\text { venus }\end{array}$ & 1.71 & 7.0 & 3.35 & 1794.9 \\
\hline Average & 1.16 & & 4.07 & \\
\hline
\end{tabular}

\section{Discussion}

Worldwide the marine fisheries primarily exploit the continental shelves and coastal waters (LONGHURST; PAULY, 2007), which have long been heavily impacted by human activity. Todos os Santos bay is a populous area which has suffered the corresponding anthropogenic impact of fishing activities, and since 1949 has been under the impact of oil effluents, after the establishment of an oil refinery and oil terminal. Overall in the coastal areas of the world the decline of fishery stocks has been caused primarily by overfishing and environmental degradation, though, according to the concept of Pauly (1988), it is closely linked to poverty. For example, in eight Asian countries (Bangladesh, India, Indonesia, Malaysia, the Philippines, Sri Lanka, Thailand, and Vietnam) and developing countries such as Brazil, the major contributor to this decline is overfishing, followed by environmental degradation (STOBUTZKI et al., 2006).

Assessment, monitoring and enforcement are crucial for the conservation and sustainable management of fishery resources. It is, further, crucial to identify the natural fluctuations of populations, which depend on the capacity of the environmental and the life cycles of the species concerned as well as on the evaluation of the effects of the anthropogenic impacts (CASPERS, 1987). Nevertheless, so that the 
assessment and monitoring may be carried out, the information on the status and trends of fisheries should be provided opportunely, in accordance with the strategy recommended by FAO (2003). There are many gaps in catch databases and our knowledge of the population dynamics of the stocks in the study area as a result of the priority accorded to the economic vision of the national fisheries policy prior to the end of the 80 's. The environmental view of fishing, which regards fishery resources as components of ecosystems, was implemented between 1991 and 1995 (DIAS-NETO, 2002, (unpublished); DIAS-NETO; MARRUL-FILHO, 2003), conjointly with the economic view. Beyond that, the available fishery information from the area has been presented as grey literature or in Government statistical bulletins (IBAMA, 2003, 2005). The main difficulty is the lack of systematic time series data on catch production.

The fisheries in the study area are typically artisanal and small-scale, being carried out with a large variety of techniques, as is generally true of the fishing on the coast of Bahia state (total of $1,188 \mathrm{~km}$, including bays and estuaries; $13 \%$ of the Brazilian coast) (IBAMA, 2003; IBAMA, 2007). A consequence of this complexity is that, due to the variety of gear used as well as to the great variety of species that compose the stocks, the assessment of catch production and of fishing effort are challenging tasks. This is typical of the worldwide scenario of artisanal fisheries and few countries have been successful in implementing adequate data collection and monitoring multispecies stocks under these conditions (VASCONCELLOS et al., 2007).

Some difficulties, such as the common names of the resources and generally low literacy among the fishermen, were encountered during the study. This is typical of artisanal fisheries in developing countries (OBURRA et al., 2002) and of fishermen living in poorer conditions. In some cases several common names are used for one particular species or many species may be grouped under one common name. The richness of the common names of Brazilian fish species has been the subject of an extensive article, and the authors concluded that it poses a problem for catch statistics because any attempt to assess the relative impact of different resources will be rendered unsatisfactory by the incomplete understanding of the nomenclature involved (FREIRE; PAULY, 2005). We attempted to cope with this problem by revising all the data on the forms carefully during the monitoring visits, but much still remains to be done. A satisfactory solution to the problem of the common names of the resources would be a collection of references to each resource, listing both the common and the scientific names.

The total proportion of the catches of fish, crustaceans and mollusks showed a similar tendency to that of those registered between 2002 and 2006 for the Bahia state coast. Also, the lists of the species caught and of the top fishery resources (sardine and anchovy, mullet, and shrimp) are similar to those available in the literature (CEPENE, 2003, 2005, 2007; IBAMA, 2008). The production was dominated by demersal species, following the tendency of the Brazilian capture marine fisheries (FAO, 2005), and also the tendency of small-scale fisheries worldwide, e.g. in Asia (STOBUTZKI et al., 2006) and in Tanzania (JIDDAWI; OEHMAN, 2002). A resource peculiar to the Brazilian fishery market is the ghost crab (Ucides cordatus), one of the main mangrove swamp resources in northeastern Brazil, the stocks of which have been managed by the government since 1989 (MOTA, 2005).

The intra-annual variability of the fish total catch (mainly ray and skate) showed similar trends in the study area to those on the whole of the coast of Bahia state during 2002, the highest production occurring during summer and spring (BAHIA PESCA, 2003). Different trends were observed depending on the resource category or local conditions, which may be associated with many factors such as oceanographic, meteorological, biological, and socioeconomic conditions, or even oil pollution. The study area is evidently subject to a meteorological seasonal cycle. In the estuary, there is a hydrographic summerwinter cycle, with prevailing marine conditions during the summer and estuarine conditions during the winter (PETROBRAS/FUSP/IOUSP, 2005, unpublished). Possibly this variability could be linked to fluctuations in the abundance of some resources, as in the case of sardine catches during fall and winter months or the catches of mullet, shrimps, crabs, and fighting conch (peguari) during the spring and summer months. Studies on population dynamics are needed for us better to understand the interactions between the populations and the environment, which may explain the great variations in abundance. However, no basic information on the population dynamics of the main species of the study area is yet available in the literature.

In summary, as expounded above, there are some similarities between our results and those found in the literature in terms of the proportion of the total catch of fish, crustaceans, and mollusks, of the resources most frequently caught, and of intra-annual variability of total catch. But in terms of production, there is a discrepancy both in total catch and in number of fishermen. At first sight, hypothetically, one may attribute this scenario to the impact of oil effluents in the study area. The decrease in fish production, even the collapse or extinction of some fish resource species has also been associated with the oil discharge (PETROBRAS/PANGEA, 2004, unpubliahed). This is a plausible argument because the 
oil refinery wastes can produce a severe, negative impact on the aquatic environment. Nevertheless, as things stand, a comparative and critical analysis of the data does not allow one to relate the decrease in the fishery resource production to the oil pollution, because different sampling designs and methodologies have been used to obtain the catch data in the available studies. In view of the lack of a robust database for purposes of comparison, we propose that our results should be used as a reference point for future monitoring of the marine fisheries of the Madre de Deus and nearby regions, with a view to improving responsible harvesting of the wild fish stocks. It serves as an initial baseline contribution to separating the effects of fishing from those of pollution and natural climatic variability.

Our first recommendation is that fisheries statistics should be improved in order to characterize the population dynamics of the fish species and to assess the environmental impact on those dynamics. We also recommend the maintenance of the monitoring of the fish species on a daily basis by the oil companies such as to cover other areas free of oil pollution to serve as control areas. The oil companies should be invited to contribute to a funding source for the purpose of establishing baseline monitoring of fisheries along the Brazilian coast so that we might thus better assess the impact of refineries, terminals, pipelines, off-shore platforms and land wells on the marine environment.

Although complex and challenging, the ideal design for assessing oil pollution impacts would be a BACI (Before/After Control/Impact) design (UNDERWOOD, 1991, 1992; SMITH, 2002). Starting from our baseline, the monitoring of the gathering of shellfish should be distinguished from that of other fishing activities. For the shellfish gathering, Cação and Caípe could be considered as replicated impacted sites, and Maria da Guarda Island and Bom Jesus as control sites. For the other fishing activities, mainly for fish capture, we propose Madre de Deus Island, Paramana and Passé as replicated impacted sites, and the same control sites as those for shellfish gathering.

Abundance of resources in terms of catch per unit effort (CPUE) should be calculated in terms of fisherman/day for each kind of gear and fishing locality in order to assess the status of individual stocks and communities. Population parameters (e.g. growth, mortality) and biological cyclic events (e.g. spawning season, larval time span) should be addressed for detecting short-term (pulse) or long-term (press) impacts (UNDERWOOD, 1991) on the resources. Initially, we propose that population studies should focus on the most abundant and economically important species: the bivalves Crassostrea rhizophorae and Anomalocardia brasiliana for shellfish gathering; the fishes Opisthonema oglinum and Mugil curema for other fishing activities.

The inventory of the common and scientific names of the resources needs to be improved to assess the relative impact on the different resources. Also of paramount importance is the monitoring of the socioeconomic dynamics of the fishing communities.

\section{ACKNOWLEDGEMENTS}

This work was conducted within the scope of the "Environmental Monitoring Program of the Estuarine Area near RLAM Refinery" coordinated by CENPES/PETROBRAS in partnership with IOUSP Instituto Oceanográfico da Universidade de São Paulo (the Oceanographic Institute of the University of São Paulo). The authors are grateful to the local fishermen and to the three fishery organizations of northern Todos os Santos Bay, Bahia, Brazil. The authors would like to thank Donald Kobayashi and an anonymous referee who worked hard to improve the manuscript through their helpful comments and suggestions.

\section{REFERENCES}

BAHIA PESCA S.A. Boletim estatístico da pesca marítima e estuarina do Estado da Bahia-2002. Salvador: Governo do Estado da Bahia. 2003. 25 p.

CASPERS, H. Changes in the benthos at a sewage Dumpsite in the Elbe estuary. In: CAPUZZO, J.; KESTER, D. (Ed.). Oceanic processes in marine pollution. Malabar, Florida: Robert E. Krieger Publishing Company, 1987. p. 201-230.

CEPENE. Boletim estatístico da pesca marítima e estuarina do Nordeste do Brasil 2002. Brasília, DF: Ministério do Meio Ambiente, Instituto Brasileiro do Meio Ambiente e dos Recursos Naturais Renováveis, Centro de Pesquisa e Gestão de Recursos Pesqueiros do Litoral Nordeste, 2003. 209 p.

CEPENE. Boletim estatístico da pesca marítima e estuarina do Nordeste do Brasil 2004. Brasília, DF: Ministério do Meio Ambiente, Instituto Brasileiro do Meio Ambiente e dos Recursos Naturais Renováveis, Centro de Pesquisa e Gestão de Recursos Pesqueiros do Litoral Nordeste, $2005.15 \mathrm{p}$.

CEPENE. Boletim estatístico da pesca marítima e estuarina do Nordeste do Brasil 2005. Brasília, DF: Ministério do Meio Ambiente, Instituto Brasileiro do Meio Ambiente e dos Recursos Naturais Renováveis, Centro de Pesquisa e Gestão de Recursos Pesqueiros do Litoral Nordeste. 2007. 211 p.

CONCHAS DO BRASIL. Conchas do Brasil. <http://www.conchasbrasil.org.br> . 2008 (July to December).

DIAS-NETO, J.; MARRUL-FILHO, S. Síntese da situação da pesca extrativa marinha no Brasil. Brasília, DF: IBAMA - Instituto Brasileiro do Meio Ambiente e dos Recursos Naturais Renováveis, 2003. 53 p. 
DIAS-NETO, J; DORNELLES, L. C. C. Diagnóstico da pesca marítima do Brasil. Brasília, DF; IBAMA, 1966. (Coleção Meio Ambiente. Série Estudos Pesca, 20. 163 p. ).

ESCHMEYER, W. N.; FONG, J. D. Species of fishes by family/subfamily. On-line version 2008/ichthyology/catalog/SpeciesByFamily.html. 2008 (July to November).

FAO. Review of the state of world marine fishery resources. Rome: Food and Agriculture Organization of the United Nations. FAO Fisheries Technical Paper 457. <www.fao.org.> July 28, 2006). 2005.

FAO. Strategy for improving information on status and trends of capture fisheries. Rome: Food and Agriculture Organization of the United Nations. Fishery Department. FAO Corporate Document Repository. <www.fao.org.> July, 28, 2006). 2003.

FIGUEIREDO, J. L. Manual de peixes marinhos do sudeste do Brasil. I. Introdução. Cações, raias e quimeras. São Paulo: Museu de Zoologia, Universidade de São Paulo, 1977. 104 p.

FIGUEIREDO, J. L.; MENEZES, N. A. Manual de peixes marinhos do sudeste do Brasil. II. Teleostei (1). São Paulo: Museu de Zoologia, Universidade de São Paulo, 1978. $110 \mathrm{p}$.

FIGUEIREDO, J. L.; MENEZES, N. A. Manual de peixes marinhos do sudeste do Brasil. III. Teleostei (2). São Paulo: Museu de Zoologia, Universidade de São Paulo, $1980.89 \mathrm{p}$.

FIGUEIREDO, J. L.; MENEZES, N. A. Manual de peixes marinhos do sudeste do Brasil. VI. Teleostei (5). São Paulo: Museu de Zoologia, Universidade de São Paulo. 2000. $116 \mathrm{p}$

FREIRE, K. M. F.; PAULY, D. Richness of common names of Brazilian marine fishes and its effect on catch statistics. J. Ethnobiol., v. 25, n. 2, p. 279-296, 2006.

GOVERNO DA BAHIA. Secretaria do Meio Ambiente e Recursos Hídricos. <www.seia.gov.ba.br.> (February, 16 2007). 2007.

IBAMA. Estatística da pesca 2000. Brasil, Grandes regiões e unidades da federação. Brasília, DF: Ministério do Meio Ambiente, Instituto Brasileiro do Meio Ambiente e dos Recursos Naturais Renováveis, 2003. 16 p.

IBAMA. Estatística da pesca 2004. Brasil, Grandes regiões e unidades da federação. Brasília, DF: Ministério do Meio Ambiente, Instituto Brasileiro do Meio Ambiente e dos Recursos Naturais Renováveis. 2005. 98 p.

IBAMA. Estatística da pesca 2005. Brasil, Grandes regiões e unidades da federação. Brasília, DF: Ministério do Meio Ambiente, Instituto Brasileiro do Meio Ambiente e dos Recursos Naturais Renováveis, 2007. 108 p.

IBAMA. Monitoramento da atividade pesqueira no litoral nordestino-Projeto Estatpesca. Boletim da Estatística da Pesca Marítima e Estuarina do Nordeste do Brasil 2006. Tamandaré, 2008. $385 \mathrm{p}$.

ITIS. Integrated Taxonomic Information System on-Line Database. <http://www.itis.gov.> 2008 (JULY TO NOVEMBER)

JIDDAWI, N. S.; OEHMAN, M. C. Marine fisheries in Tanzania. Ambio, v. 31, n.7, p. 518-527, 2002.

LONGHURST, A.; PAULY, D. Ecologia dos oceanos tropicais. Ed. atualizada. FREIRE, K. M. F.; PAULY, D. Tradução. SACCARDO, S.A.; YAMAGUTI, N.;
SOARES, L. S.; TAVARES, I. D. São Paulo: EDUSP. 2007. $419 \mathrm{p}$.

MELO, G. A. S. de. Manual de identificação dos Brachyura (caranguejos e siris) do litoral brasileiro. São Paulo: Plêiade/FAPESP, 1996. 604 p.

MELO, G. A. S. de. Manual de identificação dos Crustacea Decapoda do litoral brasileiro: Anomura, Thalassinidea, Palinuridea, Astacidea. São Paulo: Plêiade/FAPESP, 1998. $551 \mathrm{p}$.

MENEZES, N. A.; BUCKUP, P. A.; FIGUEIREDO, J. L.; MOURA, R. L. Catálogo de espécies de peixes marinhos do Brasil. São Paulo: Museu de Zoologia, Universidade de São Paulo, 2003. 160 p.

MENEZES, N. A.; FIGUEIREDO, J. L. Manual de peixes marinhos do sudeste do Brasil. IV. Teleostei (3). São Paulo: Museu de Zoologia, Universidade de São Paulo. $1980.95 \mathrm{p}$.

MENEZES, N. A.; FIGUEIREDO, J. L. Manual de peixes marinhos do sudeste do Brasil. V. Teleostei (4). São Paulo: Museu de Zoologia, Universidade de São Paulo, 1985. $105 \mathrm{p}$.

MOTA, R. I. A pesca do caranguejo-uçá nas regiões norte e nordeste. In: OLIVEIRA, G. M. (Org.). Pesca e aqüicultura no Brasil, 1991-2000: produção e balança comercial. Brasília, DF: Ibama, 2005. p. 65-68.

OBURRA, D. O.; WELLS, S.; CHURCH, J.; HORRILL, C. Monitoring of fish and fish catches by local fishermen in Kenya and Tanzania. Mar. Freshwat. Res., v. 53, n. 2, p. 215-222, 2002.

PAULY, D. Fisheries research and the demersal fisheries of Southeast Asia. In: GULLAND, J. A. (Ed.). Fish population dynamics. $2^{\text {nd }}$ ed. London: John Wiley. 1988.

RIOS, E. C. Seashells of Brazil. Rio Grande: Editora da Fundação da Universidade de Rio Grande, 1994. 492 p.

SMITH, E. P. BACI design. In: EL-SHAARAWI, A. H.; PIEGORSCH, W. W. (Ed.). Encyclopedia of Environmetrics. v. 1. Chichester: John Wiley \& Sons. p.141-148, 2002.

STOBUTZKI, I. C.; SILVESTRE, G. T.; GARCES, L. R. Key issues in coastal fisheries in South and Southeast Asia. Fish. Res., v. 78, p. 109-118, 2006.

UNDERWOOD, A. J. Beyond BACI: experimental designs for detecting human environmental impacts on temporal variations in natural populations. Austr. J. mar. Freshwat. Res., v. 42, p. 569-587, 1991.

UNDERWOOD, A. J. Beyond BACI: the detection of environmental impacts on populations in the real, but variable, world. J. experiment. mar. Biol. Ecol., v. 161, p.145-178, 1992.

VASCONCELLOS, M.; DIEGUES, A. C.; SALES, R. R. Limites e possibilidades na gestão da pesca artesanal costeira. In: COSTA, A.L. (Org.). Nas redes da pesca artesanal. Brasília, DF: IBAMA, 2007. p. 15-84.

WAKE, H. Oil refineries: a review of their ecological impacts on the aquatic environment. Estuar. coast. Shelf Sci., v. 62, n.1-2, 2005 .

\section{Sources of Unpublished Material}

ALMEIDA, V. G. (Coord.). Caracterização taxonômica, ecológica e anatômica da ictiofauna. In: AGUIAR, M. C. P. de; ALMEIDA, V. G. (Coord.). Programa de monitoramento dos ecossistemas ao norte da Baía de 
Todos os Santos. Relatório Técnico Final. Projeto 5. Salvador-Bahia, $1996.61 \mathrm{p}$.

DIAS-NETO, J. Gestão do uso de recursos pesqueiros marinhos no Brasil. Dissertação (Mestrado), Univeridade de Brasília, DF., 2002. 164 p.

GIANNINI, R. Análise da atividade pesqueira na região da Ilha de Madre de Deus, BA. São Paulo: FUNDESPA. $2000.45 \mathrm{p}$.

PETROBRAS/FUSP/IOUSP. Programa de Monitoramento Ambiental na Área de Influência da Refinaria Landulpho Alves - PROMARLAM. Relatório Final. São Paulo, 2005.

PETROBRAS/PANGEA. Diagnóstico sócio-ambiental das comunidades pesqueiras de São Francisco do Conde, Madre de Deus e Candeias. Relatório Final. Salvador, BA. 2004.89 p.
SILVA, S. A. H. (Coord.). Estudo de aspectos etnobiológicos em populações sob influência da Petrobras. In: AGUIAR, M. C. P. de; ALMEIDA, V. G.

(Coord.). Programa de monitoramento dos ecossistemas ao norte da Baía de Todos os Santos. Relatório Técnico Final. Tomo X. Salvador, Bahia, 1996. 96 p.

(Manuscript received 30 June 2009; revised 11 May 2010; accepted 28 June 2010) 